\title{
ANALISIS HUKUM ISLAM TERHADAP KEARIFAN LOKAL PENETAPAN JADWAL ADZAN
}

Studi Kasus Datar Putukrejo Loceret Nganjuk Jawa Timur

\author{
Moh. Faizur Rohman \\ UIN Sunan Ampel Surabaya \\ faza_veiro@yahoo.co.id \\ Agus Solikin \\ UIN Sunan Ampel Surabaya \\ agussolikin2@.gmail.com
}

\begin{abstract}
Adhan, which is a sign of the entry of prayer time, is usually held at the beginning of time. Different things happened in Datar, Putukrejo, Loceret, Nganjuk, East Java where the call to prayer was not done at the beginning of time, but according to the schedule set by the local kiai or village kiai. In line with that, this article is the result of studies that have been carried out at that location using qualitative research methods and data collection techniques, namely through interviews and observations. Meanwhile, the data analysis used is descriptive inductive analysis method with conclusion drawing approach. Based on the explanation of the research that has been carried out, it is concluded that the village Kiai in determining the adhan's schedule by integrating the fiqh prayer time with local wisdom in order to obtain harmony. The purpose of determining the schedule for the call to prayer is to form the character of the
\end{abstract}


importance of congregational prayers in the life of the congregation they lead.

Keywords : Village Kiai, Prayer Times, Local Wisdom, Determination of Adhan Schedules

\section{PENDAHULUAN}

Dalam perkembangannya, fikih memang bisa berubah sesuai dengan keadaan, waktu dan tempat. Seperti yang telah dikutip dari tulisan Moh. Dliya'ul Haq bahwa "fikih didefinisikan dengan pengetahuan tentang hukum-hukum syariat amaliyyah (berhubungan dengan perbuatan) yang digali dari dalil-dalil yang terperinci. Sehingga teramati dari definisi fikih yang masyhur dipakai ini, bahwa fikih tersusun atas tiga aspek, yakni aspek kewahyuan, aspek teoritis dan aspek praktis"1.

Terminology fikih yang dipaparkan tersebut menjadikan fikih merupakan satu-satunya hukum yang mempunyai ciri khas yang referensi utamanya adalah wahyu meskipun dalam penggunaannya masih adanya peran akal. Fikih bersifat dogmatis namun tetap mengarah kepada kemaslahatan baik yang bersifat duniawi maupun yang bersifat ukhrawi yang bisa didapat secara bersamaan. ${ }^{2}$

Salah satu ranah fikih yang terdapat dalam ajaran agama Islam adalah adanya kewajiban menjalankan salat 5 waktu bagi setiap muslim, yang hukum menjalankan salat tersebut adalah fardhu 'ain, artinya setiap individu bagi pemeluk agama Islam memperoleh kewajiban yang sama tiap orangnya. Al-Qur'an yang notabene merupakan pedoman/ kitab suci dalam agama Islam hanya menyebutkan secara tersirat bahwa hukum salat tersebut wajib, sedangkan terkait dengan tata cara pelaksanaannya dijelaskan secara terperinci dalam hadis hadis nabi termasuk didalamnya mengenai ketentuan waktu pelaksanaannya. Sebagaimana dalam hadis nabi yang ditulis oleh Ibn Khuzaimah dalam keterangan Riza ${ }^{3}$ (1970: 168) yang menjelaskan waktu-waktu pelaksanaan salat:

Malaikat Jibril a. s. pernah menjadi imamku dua kali, Pada kali

pertama, salat Zubur, dilakukan ketika bayangan sebesar tali sepatu.

Kemudian salat Asar ketika bayangan seukuran dengan benda

\footnotetext{
1 Moh. Dliyaul Chaq, "Penerapan Fiqh Di Tengab Perbedaan Madhhab Hukum Islam”. Tafáqquh: Jurnal Penelitian Dan Kajian Keislaman, vol. 7, no. 2, Jan. 2020, 53, doi:10.52431/tafaqquh.v7i2.217.

2 Ibid, 55

3 M. Fahmi Riza, Studi Analisis Jadwal Salat Sepanjang Masa H. Abdurrani Mahmud DalamPerspektif Astronomi. (Semarang: Tesis Pasca IAIN Walisongo,2012), hlm. 1.
} 
aslinya. Dilanjutkan dengan salat Magrib ketika Matahari terbenam dan orang-orang berbuka puasa. Salat Isya ketika ketika mega merah menghilang dan diakbiri dengan salat Subuh kala fajar menyingsing dan bagi mereka yang hendak puasa dilarang makan. Dan pada salat yang kedua kalinya, salat Zubur dilakukan kala bayangan senkuran dengan aslinya (sama seperti waktu Asar pada sore hari). Dilanjutkean dengan salat Asar ketika bayangan ukurannya dua kali lipat dari aslinya dan salat Magrib sama seperti pada salat Magrib kali pertama. Dilanjutkan dengan salat Isya pada akbir sepertiga malam dan salat Subub ketika bumi sudah mulai kelihatan. Kemudian Jibril menghampiriku dan berkata, "Wabai Mubammad, ini adalah waktu salat yang dilakukan oleh para nabi sebelum kamu. Waktu salat adalah di antara ketentuan yang ada.

Selaras dengan itu, dalam kajian-kajian fikih secara umum tentang ketentuan waktu salat dapat dipahami bahwa ${ }^{4}$, waktu salat zuhur diawali dari tergelincirnya matahari (sesaat setelah matahari mencapai titik kulminasi dalam peredaran hariannya) sampai dengan tibanya waktu salat asar yaitu panjang bayang-bayang sama dengan bendanya. Waktu asar dimulai ketika panjang bayang-bayang benda sedikit lebih panjang dari bendanya tersebut sampai tibanya waktu salat maghrib. Waktu salat maghrib dimulai pada saat terbenamnya matahari sehingga muncul mega merah sampai dengan tibanya waktu isya' yaitu dengan hilangnya mega merah. Waktu salat isya' dimulai sejak hilangnya mega merah sampai terbitnya fajar (ada yang mengatakan sampai separuh malam). Sedangkan waktu salat yang terakhir adalah waktu shubuh yang dimulai sejak terbitnya fajar sampai terbitnya matahari.

Dari penjelasan sebelumnya diketahui bahwa posisi matahari sekaligus tanda-tanda alam lainnya yang bisa disaksikan oleh panca indera sangat erat hubungannya terkait dengan penentuan awal waktu salat. Oleh karena itu menjadi suatu keniscayaan terhadap perkembangan ilmu pengetahuan dan teknologi yang pesat dan begitu cepat terhadap posisi matahari dan fenomena alam lainnya sehingga dalam penentuan waktu salat bisa menggunakan perkembangan ilmu pengetahuan terutama dalam kaitannya dengan bidang matematika dan astronomi.

Adanya perkembangan ilmu-ilmu tersebut, maka tidak heran ketika saat ini banyak bertebaran program dan jadwal waktu salat baik dalam bentuk sebuah tulisan, digital bahkan secara online. Seperti halnya yang

4, Abd Salam. Ilmu Falak Praktis (Waktu Salat, arab kiblat, dan kalender Hijriyah). (Surabaya: UINSA,tt), hlm. 75-111 
penulis contohkan yang merupakangambar waltu salat untuk wilayah Nganjuk dan sekitarnya dalam bentuk sebuah aplikasi online pada bulan Februari $2019^{5}$ :

\begin{tabular}{|c|c|c|c|c|c|c|c|c|}
\hline \multicolumn{9}{|c|}{ Jadwal Sholat untuk Nganjuk, GMT +7 } \\
\hline \multicolumn{9}{|c|}{ Februari 2019} \\
\hline \multicolumn{2}{|c|}{$\leftarrow$ sebelum } & Pilih Kota & \multicolumn{2}{|l|}{ Nganjuk } & \multicolumn{2}{|l|}{$\mathbf{v}$} & \multicolumn{2}{|c|}{ sesudah $\Rightarrow$} \\
\hline Tanggal & Imsyak & Shubuh & Terbit & Dhuha & Dzuhur & Ashr & Maghrib & Isya \\
\hline 01 & $04: 02$ & $04: 12$ & 05:31 & 05:55 & $11: 48$ & $15: 07$ & $18: 01$ & $19: 14$ \\
\hline 02 & & & $05: 31$ & & & & & \\
\hline 03 & $04: 03$ & & 05:31 & & & & 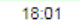 & \\
\hline 04 & $04: 04$ & $04: 14$ & $05: 31$ & 55 & 48 & 15:06 & $18: 01$ & $19: 14$ \\
\hline 05 & $04: 04$ & $04: 14$ & $05: 32$ & 56 & 48 & 15:06 & $18: 01$ & $19: 13$ \\
\hline 06 & $04: 05$ & $04: 15$ & $05: 32$ & $5: 56$ & 48 & 15:06 & $18: 01$ & $19: 13$ \\
\hline 07 & $04: 05$ & $04: 15$ & $05: 32$ & $05: 56$ & 48 & $15: 05$ & $18: 00$ & $19: 13$ \\
\hline 08 & $04: 05$ & $04: 15$ & $05: 33$ & $05: 57$ & & $15: 05$ & & $19: 13$ \\
\hline 09 & $04: 06$ & 16 & $05: 33$ & & & $15: 04$ & & $19: 12$ \\
\hline 10 & $04: 06$ & & $05: 33$ & 7 & & 1 & 1 & $19: 12$ \\
\hline 11 & 04 & & 05 & & & & & \\
\hline 12 & 04:07 & & $05: 33$ & & & 3 & 1 & 19 \\
\hline 13 & 04:07 & 17 & $05: 34$ & & 49 & $15: 02$ & 17 & $19: 11$ \\
\hline 14 & $04: 08$ & $04: 18$ & $05: 34$ & $05: 58$ & 49 & $15: 02$ & 17 & 19 \\
\hline 15 & $04: 08$ & $04: 18$ & $05: 34$ & $05: 58$ & 49 & $15: 01$ & 17 & 19 \\
\hline 16 & $04: 08$ & $04: 18$ & $05: 34$ & $05: 58$ & $11: 48$ & $15: 00$ & $17: 59$ & $19: 10$ \\
\hline 17 & $04: 08$ & $04: 18$ & $05: 34$ & $05: 58$ & $11: 48$ & $15: 00$ & $17: 58$ & $19: 10$ \\
\hline 18 & $04: 09$ & $04: 19$ & $05: 34$ & $05: 58$ & $11: 48$ & $14: 59$ & $17: 58$ & $19: 09$ \\
\hline 19 & $04: 09$ & & $05: 3$ & & & $14: 58$ & 17 & $19: 09$ \\
\hline 20 & $04: 0$ & & & & & & & $19: 09$ \\
\hline 21 & $04: 09$ & $04: 19$ & $05: 35$ & 05:59 & $11: 48$ & $14: 57$ & $17: 57$ & $19: 08$ \\
\hline 22 & $04: 10$ & $04: 20$ & $05: 35$ & 05:59 & $11: 48$ & $14: 56$ & $17: 57$ & $19: 08$ \\
\hline 23 & $04: 10$ & $04: 20$ & $05: 35$ & 05:59 & $11: 48$ & $14: 55$ & $17: 57$ & $19: 07$ \\
\hline 24 & $04: 10$ & $04: 20$ & $05: 35$ & $05: 59$ & $11: 48$ & $14: 54$ & $17: 56$ & $19: 07$ \\
\hline 25 & $04: 10$ & $04: 20$ & $05: 35$ & $05: 59$ & $11: 48$ & $14: 53$ & $17: 56$ & $19: 07$ \\
\hline 26 & $04: 10$ & $04: 20$ & $05: 35$ & 05:59 & $11: 47$ & $14: 52$ & $17: 56$ & $19: 06$ \\
\hline 27 & $04: 10$ & & $05: 35$ & 05 & & $14: 51$ & $17: 55$ & $19: 0$ \\
\hline 28 & 04:11 & $04: 21$ & $05: 35$ & $05: 59$ & $11: 47$ & $14: 50$ & $17: 55$ & $19: 05$ \\
\hline
\end{tabular}

Ketika diteliti lebih jauh ternyata jadwal yang telah beredar di masyarakat dalam praktik penerapan di lapangan akan berbeda dari apa yang sudah dijadwalkan. Jadwal yang digunakan antara 1 jadwal dengan jadwal lain bisa selisih 3 sampai 5 menit atau bahkan bisa lebih dari itu. Perbedaan jadwal ini akan semakin terlihat ketika kita masuk lebih jauh ke dalam masyarakat pedesaan yang jadwal waktu salat tersebut sangat erat dihubungkan dengan penetapan waktu azan disebuah masjid atau musholla yang ada ditengah-tengah masyarakat. Seperti halnya yang disampaikan oleh Sutinah yang menjelaskan bahwa "pada umumnya masyarakat muslim di Indonesia lebih banyak mengetahui waktu salat dengan sistem yang masih tradisional yaitu dengan cara mendengarkan suara azan di Masjid, kentongan, atau suara bedug". ${ }^{6}$.

Pada akhirnya, banyaknya fenomena perbedaan waktu azan di masyarakat dikarenakan kumandang azan dari 1 masjid dengan masjid lainnya terdapat perbedaan selisih waktu, bahkan perbedaan tersebut bisa

5

https://www.jadwalsholat.org/adzan/monthly.php? q=c9d4d261da\&type $=2 \& i d=167$ $\& \mathrm{~m}=2 \& \mathrm{y}=2019$

${ }^{6}$ Sutinah. Sistem Informasi Penjadwalan Waktu Sholat Berbasis Mikrokontroler ATMega16. (Bekasi: Informatics For Educators And Professionals P2M STMIK BINA INSANI,2006), hlm. 37., 
cukup jauh selisih waktunya. Seperti halnya yang tejadi di Dusun Datar Desa Putukrejo Kecamatan Loceret Kabupaten Nganjuk Jawa Timur. Jadwal salat yang diterapkan di desa tersebut sedikit berbeda dengan jadwal awal waktu salat pada umumnya, informasi ini diperoleh penulis dalam observasi awal tanggal 24 Februari 2019 di salah satu Musholla yang ada di dusun Datar Desa Putukrejo, yaitu Musholla Al faruq (Lor) yang dalam penentuan awal waktu salat ditetapkan oleh kiai kampung setempat dengan kesimpulan sebagai berikut:

\begin{tabular}{|c|c|c|c|c|}
\hline Shubuh & Zuhur & Asar & Maghrib & Isya' \\
\hline $04.30 \mathrm{Wib}$ & $12.30 \mathrm{Wib}$ & $16.30 \mathrm{Wib}$ & Sesuai Jadwal & $19.05 \mathrm{Wib}$ \\
\hline
\end{tabular}

Berdasarkan jadwal tersebut jika dibandingkan dengan jadwal dari aplikasi yang penulis sajikan sebelumnya yaitu pada tanggal 24 Pebruari, maka akan diperoleh Salat shubuh terjadi selisih 10 menit, Salat zuhur terjadi selisih 42 menitl, Salat asar terjadi selisih 94 menit dan Salat isya terjadi selisih 2 menit, dengan jadwal Musholla lebih dulu

Hipotesa awal yang dilakukan oleh penulis menunjukkan bahwa kearifan lokal yang terdapat di daerah tersebut sedikit banyak mempengaruhi terhadap penetapan permulaan waktu salat, yang mengakibatkan terjadinya selisih waktu azan dengan jadwal yang sebenarnya bahkan selisihnya bisa berbeda cukup jauh. sebagaimana yang dituliskan oleh Butar-butar bahwa kearifan lokal jika tidak bertentangan dengan syariat, maka bisa menjadi perekat dalam ajaran agama. ${ }^{7} \mathrm{Hal}$ ini menarik untuk dibahas lebih lanjut dan mendorong penulis untuk mengkaji dan menganalisis terkait dengan langkah dan tujuan kiai tersebut dalam menetapkan jadwal azan.

\section{METODE PENELITIAN}

Guna mencapai tujuan yang ditetapkan, sebagaimana dijelaskan dalam latar belakang, maka metode penelitian yang dilakukan yaitu

\section{Jenis Penelitian}

Menurut Suryana ${ }^{8}$ penelitian dapat dibedakan menjadi dua jenis yaitu berdasarkan sifat masalahnya dan berdasarkan tujuannya. Berdasarkan sifat masalahnya penelitian ini dirancang sebagai penelitian deskriptif yang bertujuan untuk membuat diskripsi secara sistematis, faktual dan akurat mengenai fakta-fakta yang ada, terhadap upaya yang coba dijalankan oleh kiai dalam menetapkan jadwal waktu azan salat yang berbeda dari jadwal semula di Datar, Putukrejo, Loceret, Nganjuk. Maka

\footnotetext{
${ }^{7}$ Arwin Butar Butar, , Eai Esai Astronomi Islam, (Medan, UMSU Press,2015), hlm. 71.,

${ }^{8}$ Suryana, Metodologi Penelitian, (Bogor: Universitas Pendidikan Indonesia, 2010), hlm. 18
} 
berdasar hal tersebut, penelitian ini termasuk dalam jenis penelitian diskriptif kualitatif.

\section{Sumber Data Penelitian}

Menurut Moleong 9 (2004:157), disebutkan bahwa kata-kata ataupun tindakan merupakan sumber data utama dalam penelitian kualitatif. Maka berdasarkan hal tersebut yang menjadi salah satu sumber utama dalam penelitian ini adalah kata-kata yang diperoleh dari hasil wawancara dan dokumen-dokumen terkait dengan fokus penelitian.

Metode Pengumpulan dan Analisis Data

Pada penelitian ini metode pengumpulan data yaitu dengan cara wawancara dan penelaahan literatur-literatur Hukum Islam dan dokumen-dokumen yang berhubungan dengan obyek penelitian, serta analisis data dengan menggunakan analisis deskriptif induktif. Wawancara yang telah dilakukan yaitu dengan kiai Yanto yang merupakan kiai di desa yang menjadi lokasi penelitian ini, bapak Romlan, bu Patminah, bu Enni yang merupakan Jamaah, dan bapak Sugito yang merupakan kepala desa setempat.

\section{PEMBAHASAN}

\section{Kiai Desa}

Kiai sebagaimana dituliskan oleh Yudi Trisno Widodo ${ }^{10}$ bahwa: "Kiai itu merupakan sebuah gelar yang diberikan kepada masyarakat kepada sesorang yang gelar yang diberikan kepada seseorang yang mempunyai ilmu yang diyakini tinggi dibidang agama dalam bal ini agama Islam”.

Desa sebagaiamana dijelaskan dalam Undang-Undang Republik Indonesia Nomor 6 Tahun 2014 Tentang Desa, disebutkan bahwa:

"Desa adalah kesatuan masyarakat bukum yang memiliki batas wilayah yang berwenang untuk mengatur dan mengurus urusan pemerintahan, kepentingan masyarakat setempat berdasarkan prakarsa masyarakat, hak asal usul, dan/atau hak tradisional yang

\footnotetext{
${ }^{9}$ Lexy J, Moleong, Metodologi Penelitian Kualitatif, (Bandung: PT Remaja Rosdakarya, 2005) blm, 157

${ }^{10}$ Yudi Widodo. Trisno, Gaya Kepemimpinan Kiai Yusuf Dalam Pengembangan Pondok Pesantren Assalafi Al-Aafiyy'ah Waylaga Sukabumi Kota Bandar Lampung,(Lampung: UIN Raden Intan., 2018) hlm 34 - 35
} 


\section{diakui dan dihormati dalam sistem pemerintahan Negara Kesatuan Republik Indonesia”}

Bahwa menurut penjelasan diatas terkait dengan maksud dan pengertian dari Kiai dan desa, maka dapat disimpulkan bahwa yang dimaksud dengan kiai dan desa dalam penelitian ini adalah seseorang yang mempunyai pengetahuan ilmu agama yang lebih dibandingkan dengan warga masyarakat lainnya di Dsn. Datar Ds. Putukrejo Kec. Loceret Nganjuk dalam bidang ilmu agama, sehingga masyarakat setempat memberi penghargaan dengan sebuah penghormatan yang lebih khusus dibandingan dengan masyarakat biasa pada umumnya.

Berpedoman pada pengertian kiai yang telah diuraikan diatas, bahwa seorang kiai diyakini oleh masyarakat mempunyai keilmuan yang mumpuni terlebih dalam bidang agama. Lebih lanjut seperti yang dijelaskan oleh Masroratul ${ }^{11}$ terkait dengan kiai bahwa kiai dalam kehidupan warga yang dipimpinnya memiliki fungsi antara lain:

Satu: Sebagai "guru ngaji", telah masyhur dimasyarakat bahwa tugas kiai sebagai guru ngaji dilaksanakan dalam bentuk lebih khusus dalam jabatan dalam tugas seorang mubalig, guru diniyyah/pengasuh, khatib salat jum'at/ied, qori' kitab salaf dalam sistem sorogan atau bandongan.

Dua: Tabib/ penjampi, tugas kiai sebagai tabib terdapat dalam bentuk-bentuk diantaranya dengan mengobati pasien dengan do'a (rukyah), mengobati menggunakan alat non medis lainnya seperti menggunakan air, akik atau sarana lainnya, mengobati dari roh halus/jin, dan perantara permohonan kepada Tuhan.

Tiga: Rois/Imam, kiai sebagai imam tercermin dalam tugastugasnya sebagai imam salat rowatib dan salat sunnah lainnya, imam ritual slametan, imam tahlilan, dan imam prosesi perawatan kematian dan penyampai maksud/hajat,

Empat: Pegawai pemerintah/ jabatan formal, kiai sebagai pegawai pemerintah biasanya menempati tugas-tugas sebagai Kepala KUA atau penghulu, Modin, guru agama Islam, pegawai dinas/ partai politik, dan pengurus organisasi kemasyarakatan lainnya.

Lima: Faktor lain yang selain dengan yang disebutkan diatas. Fungsi ini sebagai penjelas terhadap orang yang memiliki keistimewaan di mata masyarakat santri antara lain sebagai berikut; Factor performance atau penampilan, Faktor keajaiban (karomah), Faktor keturunan dan Faktor lingkungan.

\footnotetext{
${ }^{11}$ Masroratul Fadlilah, Kepemimpinan Kiai Di Pondok Pesantren Mahasiswa Al-Jihad Surabaya (Surabaya: UINSA,2018), hlm. 40-41
} 


\section{Ketentuan Waktu Salat}

Ketentuan Waktu salat dalam kajian ilmu falak sebagaimana telah kami uraikan dalam latar belakang secara umum ketentuan waktu salat dapat dipahami bahwa ${ }^{12}$, waktu salat zuhur diawali dari tergelincirnya matahari (sesaat setelah matahari mencapai titik kulminasi dalam peredaran hariannya) sampai dengan tibanya waktu salat asar yaitu panjang bayang-bayang sama dengan bendanya. Waktu asar dimulai ketika panjang bayang-bayang benda sedikit lebih panjang dari bendanya tersebut sampai tibanya waktu salat maghrib. Waktu salat maghrib dimulai pada saat terbenamnya matahari sehingga muncul mega merah sampai dengan tibanya waktu isya' yaitu dengan hilangnya mega merah. Waktu salat isya' dimulai sejak hilangnya mega merah sampai terbitnya fajar (ada yang mengatakan sampai separuh malam). Sedangkan waktu salat yang terakhir adalah waktu shubuh yang dimulai sejak terbitnya fajar sampai terbitnya matahari.

Kearifan Lokal dalam Islam

Iin Warrin Bayari ${ }^{13}$ dalam memberikan pengertian keraifan lokal yaitu

"Sikap dan perilaku masyarakat yang mentradisi, karena didasari oleh nilai-nilai yang diyakini kebenarannya ini merupakan wujud dari kearifan lokal. (Maryani,2011) Gobyah 2003 (Ernawi, 2010) memaknai kearifan lokal (lokal wisdom):'... sebagai suatu kebenaran yang telah mentradisi atau ajeg dalam suatu daerah'. Masyarakat pada dasarnya tidak dapat dilepaskan dari nilai-nilai tradisi dan budaya yang turun dari generasi satu ke genarasi seterusnya. Menurut Geerts, 2007, (dalam Ernawi, 2010) dikatakan bahwa: '...kearifan lokal merupakan entitas yang sangat menentukan harkat dan martabat manusia dalam komunitasnya'. Oleh karena itu manakala nilai-nilai tradisi yang ada pada masyarakat tercerabut dari akar budaya lokal, maka masyarakat tersebut akan kebilangan identitas dan jati dirinya, sekaligus kebilangan pula rasa kebanggaan dan rasa memilikinya. Betapa besarnya kedudukan dari nilai-nilai kearifan lokal, karena menurut Sartini (2006) peran dan fungsi kearifan lokal

\footnotetext{
12 Abd. Salam, Ilmu Falak Praktis (Waktu Salat, arab kiblat, dan kalender Hijriyab). (Surabaya: UINSA,tt), hlm. 75-111

13 Iin Warrin Bayari, Nilai-Nilai Kearifan Lokal (Local Wisdom) Tradisi Memitu Pada Masyarakat Cirebon(Studi Masyarakat Desa Setupatok Kecamatan Mundu),(Cirebon: Edunomic Jurnal Volume 2 No. 12014 )
} 
adalah: (1) untuk konservasi dan pelestarian sumber daya alam, (2) pengembangan sumber daya manusia, (3) pengembangan kebudayaan dan ilmu pengetabuan, (4) sebagai sumber petuah/kepercayaan/sastra dan pantangan, (5) sebagai sarana mebentuk. membangun intregrasi komunal, (6) sebagai landasaan etika dan moral, (7) fungsi politik. (dalam Wuryandari,2010)"

Berangkat dari pengertian tentang kearifan lokal tersebut dan data yang didapatkan penulis dari Pemerintah Desa Putukrejo, Kec. Loceret, Kab. Nganjuk menyatakan bahwa $72 \%$ masyarakat putukrejo bekerja sebagai petani dan menggantungkan pekerjaan pada area persawahan. ${ }^{14}$ maka kearifan lokal yang dibahas oleh penulis lebih difokuskan kepada hal yang terkait dengan persawahan.

Selaras dengan itu Bapak Romlan, salah seorang petani setempat memberikan penjelasan mengenai pola kehidupan masyarakat pertanian yakni:

'Di kampung ini, satu tabun tanam empat kali yaitu padi dua kali, satu kali jagung, dan terakhir kedelai. Ini tanaman yang umum ditanam warga, namun ada pula yang tanam sayuran seperti kangkung, kacang, terong untuk dijual ke pasar. Ada pula yang tanam bawang merah, kalau bawang merah satu tabun bisa lima kali tanam"15

Hal ini selaras dengan hasil observasi yang dilakukan oleh penulis bahwa penulis melihat berbagai tanaman yang ditanam oleh warga setempat dipersawahan, seperti kangkung, jagung, bawang merah dan sayuran-sayuran lainnya. ${ }^{16}$ Lebih lanjut bapak Romlan memaparkan pola kerja petani di desa setempat bahwa:

"Namanya petani ya kerjanya di sawab, setiap hari di sawah, bearangkat biasanya pukul 06.00, pukul 10.30 pulang, nanti balik lagi pukul 13.00 dan pulang pukul 16.00 biasanya juga satu bari di sawah terus, pulang pas waktu salat zubur saja". ${ }^{17}$

Konteks masyarakat setempat dalam menjalankan kehidupan beragama tidak terlepas dari uraian yang disampaikan oleh Faisol Rizal bahwasanya manusia dalam menjalankan peran sebagai khalifah dibumi

14 Wawancara dengan bapak Sugito kepala desa setempat Pada Tanggal 12 Agustus 2019

15 Hasil Wawancara Dengan Bapak Romlan Yang Dilaksanakan Pada Tanggal 13 Agustus 2019

16 Observasi pada tanggal 12 - 13 September 2019

17 ibid 
disamping membutuhkan eksistensi agama sebagai kebutuhan primer, juga membutuhkan peran social sebagai wujud bahwa manusia merupakan makhluk social. Interaksi sosial yang terbentuk dalam masyarakat secara dinamis lambat laun akan menjadi suatu nilai yang dapat dijadikan sebagai sebuah acuan disamping agama, yang disebut dengan budaya. ${ }^{18}$

Dalam pandangan kuntowijoyo, ${ }^{19}$ agama dan budaya dalam perkembangan sejarah memang saling mempengaruhi satu sama lain, hal ini tidak lain dikarenakan antara agama dan budaya merupakan samasama berfungsi sebagai sebuah nilai dan symbol ditengah kehidupan masyarakat. Jikalau agama merupakan sebuah symbol ketaatan antara manusia dengan tuhannya, maka budaya sebagai sebuah symbol eksistensi manusia yang membuat manusia bisa bertahan dalam lingkungannya. Disamping itu, antara agama dengan budaya juga tidak bisa disamakan begitu saja, masih terdapat perbedaan yang mendasar antar keduanya, diantaranya adalah agama bersifat final, meskipun sifat final dalam agama tersebut bisa berubah sebagaimana budaya, namun kebenarannya adalah kebenaran yang hakiki karena bersumber dari tuhan. Sedangkan budaya dapat berubah seiring berubahnya nilai-nilai yang diyakini oleh masyarakat, meskipun kebenarannya bukan kebenaran mutlak. ${ }^{20}$

\section{LANGKAH KIAI DALAM PENETAPAN JADWAL ADZAN}

Dalam pemahaman konteks kiai disini adalah kiai desa yang merupakan seorang yang dihormati karena keilmuan agamanya, terlebih yang berada di wilayah Dusun Datar Desa Putukrejo Kec. Loceret Kab. Nganjuk. Dalam titik pembahasan mengenai kiai yang berperan besar dalam menetapkan jadwal azan waktu salat, penulis lebih memfokuskan penelitian terhadap seorang kiai yang menetapkan jadwal azan waktu salat yang ada di musholla al-Faruq Desa Datar sebagai objek penelitian. Oleh karena itu kiai desa yang dimaksud disini adalah Kiai Yanto sebagai tokoh agama di wilaya musholla al-faruq desa Datar. ${ }^{21}$

\footnotetext{
${ }^{18}$ Faisol Rizal, "Agama Dalam Pluralitas Budaya”. Tafáqquh: Jurnal Penelitian Dan Kajian Keislaman, vol. 7, no. 2 , Desember 2019, Hal: 68. https://doi.org/10.52431/tafaqquh.v7i2.221

${ }^{19}$ Kuntowijoyo, Muslim Tanpa Masjid (Bandung: Mizan.2001), 201

${ }^{20}$ Rizal, F. “Agama Dalam Pluralitas Budaya”, 70-71. https://doi.org/10.52431/tafaqquh.v7i2.221

${ }^{21}$ Kiai Yanto ini merupakan kiai di lokasi tersebut yang merupakan tokoh dan sekaligus sebagai aktor yang menetapkan jadwal waktu salat tersebut. Kiai Yanto ini sehari - hari yang menjadi imam di mushola tersebut
} 
Selanjutnya, untuk lebih memudahkan analisis yang dilakukan penulis, terlebih dahulu penulis akan menganalisa satu persatu waktu azan muai dari waktu shubuh, zuhur, ashar, maghrib dan isya'. Analisis yang dilakukan adalah dengan menyajikan terlebih dahulu data-data tentang waktu salat dalam berbagai perspektif, baik perspektif fikih, astronomi ataupun perspektif kearifan lokal yang dalam wilayah objek penelitian. Sehingga akan memperoleh suatu data yang utuh dan mengetahui motivasi di dalam kearifan lokal tersebut dalam penetapan waktu azan.

Pertama: Peran Kiai Desa Dalam Mengintegrasikan Waktu Salat dan Kearifan Lokal dalam Penetapan Jadwal Azan Salat Shubuh

Dalam ketentuan fikih yang sebelumnya sudah dijelaskan oleh penulis bahwa waktu salat shubuh adalah dimulai sejak terbitnya fajar sampai terbitnya matahari. Ketentuan ini juga sesuai dengan keterangan yang diberikan Kiai Yanto kepada penulis saat menjelaskan waktu shubuh:

"Waktu shubub itu, mulai terbitnya fajar shidiq,ciri-cirinya yaitu jikea di timur mulai terang dari arah selatan ke utara terang semua, sampai terbitnya Matahari”. ${ }^{22}$

Dalam ketentuan fikih mengenai waktu shubuh, terbitnya fajar shadiq ini bisa dipahami secara sains, bahwa dalam tinjauan astronomi fenomena tersebut menjukkan posisi Matahari berada pada posisi 20 derajat dibawah ufuk, ${ }^{23}$ posisi Matahari pesrpektif astronomi ini yang kemudian dijadikan acuan ketinggian dalam perhitungan awal waktu shubuh.

Sedangkan dalam perspektif kearifan lokal yang ada, menarik untuk dibahas kembali terkait dengan apa yang disampaikan oleh pak Romlan sebelumnya bahwa saat shubuh sebagian besar penduduk setempat masih di rumah dan baru berangkat ke sawah pada pukul $06.00 \mathrm{Wib}^{24}$ Akan tetapi justru berbeda dengan ibu Patminah yang berprofesi sebagai pedagang. Beliau (Ibu Patminah) berangkat ke pasar menuggu setelah shubuh selesai, beliau tidak berangkat sebelum shubuh belum selesai25.

\footnotetext{
22 Wawancara dengan kiai yanto pada tanggal 12 September 2019

${ }^{3}$ Azhari, Susiknan, Perjumpaan Khazanah Islam dan Sains Modern, Yogyakarta:Suara Muhammadiyah. 2007) hlm 69

${ }^{24}$ Hasil wawancara dengan bapak Romlan yang dilaksanakan pada tanggal 13 Agustus 2019

${ }^{25}$ Hasil wawancara dengan ibu Patminah yang dilaksanakan pada tanggal 29 Agustus 2019
} 
Maka dari itu, Kiai Yanto dalam menetapkan azan waktu shubuh langsung mematok jadwal pukul 04.30 Wib, beliau berpandangan bahwa waktu tersebut berdasar atas fikih dan kearifan lokal masyarakat setempat. menariknya dalam wawancara beliau menyatakan bahwa:

"W arga disini rata-rata petani, kalau azan mengikuti ketentuan yang ada, artinya sesuai fikih, saya khawatir tidak ada yang jamaah, misal seperti sekarang waktu shubuh seharusnya pukul 04 kurang, kalau saya azan pukul 04 kurang sesuai fikih, kesannya masib malam, pukul 04.30 itu saya kira cukup baik, prinsipnya lebih baik siang namun jamaah, dari pada salat di awal namun salat sendiri. Selain itu, saya ingin, setelah jamaah subub saya tidak langsung pulang, sebelum dhuba. Artinya saya ingin shububan, terus drikiran sampai dhuba. Yang nomor dua, bidup di desa itu jamaah lebih seneng waktu yang pasti gampang untuk ngingatnya, kalau azan berubah-ubah, kadangan jam 4, kadang jam 4 kurang, bener secara fikih, namun masyarakat bingung". 26

Berasal dari pemaparan diatas dapat dipahami bahwa penetapan azan waktu shubuh ditetapkan oleh kiai Yanto pada pukul 04:30 Wib, sehingga langkah tersebut merupakan jalan tengah untuk menjembatani awal waktu salat yang ada dalam ketentuan ajaran agama yang diintegrasikan dengan kearifan lokal. Menariknya, dalam penetapan jadwal waktu shubuh tersebut, ada tujuan lain disamping mengintegrasikan antara fikih dengan kearifan lokal yang dilakukan kiai Yanto dalam menetapkan azan shubuh pukul 04.30 yakni selain waktu salat shubuh akan lebih mudah diingat oleh para jamaah (istiqamah), juga yang lebih penting adalah agar masyarakat bisa jamaah shubuh di musholla setempat.

Kedua: Peran Kiai Desa Dalam Mengintegrasikan Waktu Salat dan Kearifan Lokal dalam Penetapan Jadwal Azan Salat Zuhur.

Secara fikih waktu salat zuhur diawali dari tergelincirnya matahari sampai dengan panjang suatu bayang-bayang sama dengan panjang bendanya. Dalam perspektif astronomi waktu zuhur dapat dipahami dengan posisi matahari sebentar meninggalkan meridian, biasanya diambil sekitar 2 menit setelah lewat tengah hari. ${ }^{27}$

Disisi yang lain kearifan lokal dalam menyikapi waktu zuhur, menurut keterangan dari pak Romlan bahwa warga dusun Datar desa

\footnotetext{
${ }^{26}$ Wawancara dengan kiai yanto pada tanggal 12 September 2019

27 Azhari, Susiknan, Perjumpaan Khazanah Islam dan Sains Modern, Yogyakarta:Suara Muhammadiyah. 2007) hlm 66
} 
Putukrejo pada siang hari baru pulang dari sawah yaitu sekitar pukul $10.30 \mathrm{Wib}^{28}$

Oleh karena itu berdasar dari 3 pesrpektif data-data diatas digunakan kiai Yanto untuk menetapkan waktu azan zuhur. Beliau (kiai Yanto) menetapkan waktu azan zuhur pada pukul 12.30 Wib. Sesuai dengan penjelasan yang beliau sampaikan bahwa:

"Waktu zubur itu dimulai Matahari mulai ke barat, ciri ciri Matahari mulai ke barat itu kalau bayangan kita mulai ke Timur kapan bayangan mulai ke timur itu tidak ajeg kadang kala bisa cepat, kadang kala lambat, buktinya sekarang saja belum pukul 12 siang sudah zubur, kalau azan zubur tidak dibuat ajeg jamnya warga akan bingung, kadang jam 12 lebih, kadang jam 12 kurang, yang di sawah bingung. Selain itu, warga sini itu, pulang dari sawah rata-rata jam setengah suwelas. Setelah sampai rumah, tidak langsung istirahat tidur siang, masih ada yang ngombeni sapi, baru bersib-bersib, makan dan tidur. Tidur itu pun, saya yakin tidak. bisa langsung tidur, baru 30 menit berikutnya bisa tidur. Jadi anggap saja, jam setengah suwelas pulang dari sawah, setengah jam ngombeni sapi, baru bersibberish,makan, setengah jam lagi baru tidur, kasihan kalau jam 12 saya adzan, biar agak pulas setengah siji saya azan zubur. Yang nomor dua, saya ingin ngamalne hadis nabi, kalau bisa sebelum salat zubur istirahat dulu. Sebingga terakbir azan zubur setengah siji, selain ajeg, makmumnya ada, dan warga bisa siap siap ke sawah lagi". ${ }^{29}$

Dari penjelasan kiai Yanto terkait dengan penetapan waktu azan zuhur yang ditetapkan pada pukul 12.30 Wib menunjukkan bahwa kiai Yanto faham betul akan kondisi masyarakat sekitar. Oleh karenanya beliau menggabungkan antara teori fikih, astronomi dengan kearifan warga setempat. Maka dari penetapan beliau berharap:

"Warga pulas istirahatnya, sehingga ketika azan zubur pukul 12.30 wib bisa ikut jamaah Beliau ingin menjalankan ajaran Nabi tentang sebelum zalat zubur disunnabkan untuk. istrabat dulu". ${ }^{30}$

Ketiga: Peran Kiai Dalam Mengintegrasikan Waktu Salat dan Kearifan Lokal dalam Penetapan Jadwal Azan Salat Asar

\footnotetext{
${ }^{28}$ Hasil wawancara dengan bapak Romlan yang dilaksanakan pada tanggal 13 Agustus 2019

${ }^{29}$ Wawancara dengan kiai yanto pada tanggal 12 September 2019

30 ibid
} 
Dalam pespektif fikih, waktu asar dimulai dari panjang bayangbayang benda sama panjang dari bendanya tersebut sampai dengan terbenamnya matahari di ujung barat. Jika waktu asar diasumsikan jatuh diawal waktunya yakni pukul $15.00 \mathrm{Wib}$, maka warga setempat Dusun Datar masih banyak yang berada disawahnya untuk bekerja, hal ini disampaikan oleh bapak Romlan ${ }^{31}$. Penjelasan pak Romlan ini sejalan dengan penjelasan yang disampaikan kiai Yanto bahwa:

"Warga di sini, pulang dari sawah sekitar pukul empat sore, jika azan pukul 03 saja warga akan bingung, seperti yang terjadi di desa sebelah baru baru ini, ada masjid yang azan sesuai awal waktu, warganya yang petani bingung, karena baru saja berangkat ke sawah pukul 01 kok sudah asar, melihat ini saya tetapkan azan asar pukul setengah lima sore. Sehingga warga biar bisa ikut jamaah asar. Kalaupun mereka masib di sawah, minimal azan di musholla ini bisa dijadikan tanda bahwa sebentar lagi maghrib, segera pulang dan segera salat asar". 32

Seperti halnya dalam penjelasan sebelumnya. Kiai Yanto dalam menetapkan azan waktu asar tidak diawal waktu asar melainkan pukul 04.30 Wib. Pertimbangan ini didasarkan pada budaya kerja warga sekitar yang mayoritas sebagai petani, disamping itu pentingnya bisa salat berjamaah bagi penduduk sekitar juga menjadi salah satu pertimbangan yang penting menurut pandangan kiai Yanto. Sebagai panutan di masyarakat, kia Yanto masih berfikir positif terhadap masyarakat sekitar, hal ini tercermin dari penjelasannya:

"Kalaupun mereka masih di sawah, minimal azan di musholla ini bisa dijadikan tanda babwa sebentar lagi maghrib, segera pulang dan segera salat asar". ${ }^{3}$

Keempat: Peran Kiai Dalam Mengintegrasikan Waktu Salat dan Kearifan Lokal dalam Penetapan Jadwal Adzan Salat Maghrib

Dalam fikih waktu salat maghrib dimulai pada saat terbenamnya matahari sehingga muncul mega merah sampai dengan tibanya waktu isya' yaitu dengan hilangnya mega merah. Dalam penetapan azan waktu maghrib ini kiai Yanto tidak menetapkannya secara pasti seperti waktu salat sebelumnya, akan tetapi dituliskan kondisional seperti yang beliau jelaskan bahwa:

\footnotetext{
${ }^{31}$ Hasil wawancara dengan bapak Romlan yang dilaksanakan pada tanggal 13 Agustus 2019

32 Wawancara dengan kiai yanto pada tanggal 12 September 2019

33 ibid
} 
"Maghrib itu, mulai dari terbenamnya Matahari, terbenamnya Matahari itu juga tidak ajeg. Akibatnya maghrib juga tidak ajeg, kadang bisa jam setengah enam, kadang bisa jam 6 sore. Mengapa tidak saya tetapkan seperti shubuh dan zubur?, karena maghrib warga sudah di rumah, jadi azan sesuai jadwal tidak ada masalah, pasti ada jamaabnya". 34

Dari penjelasan kiai Yanto ini, bisa penulis simpulkan bahwa sosok kiai Yanto merupakan seorang yang dapat memahami kajian awal waktu salat secara utuh. Seperti halnya waktu salat maghrib yang sangat erat kaitannya dengan posisi matahari saat tenggelam, yang waktunya tidak pasti dan berubah-ubah. Pada akhirnya waktu azan maghrib tidak ditetapkan secara pasti karena disamping waktu maghrib yang sempit, juga jika dihubungkan dengan budaya kerja, maka saat maghrib warga masyarakat yang bekerja disawah sudah berada di rumahnya masingmasing dan harapan besar warga sekitar untuk bisa ikut jamaah salat terbuka lebar.

Kelima: Peran Kiai Dalam Mengintegrasikan Waktu Salat dan Kearifan Lokal dalam Penetapan Jadwal Azan Salat Isya'.

Dalam fikih seperti yang telah penulis sebutkan sebelumnya bahwa waktu salat isya' dimulai sejak hilangnya mega merah sampai terbitnya fajar. Hilangnya mega merah, masih di bab II juga penulis uraikan secara sains atau astonomi yaitu ketika ketinggian matahari 18 derajat di bawah ufuk $^{35}$.

Yang menarik dalam penetapan azan waktu isya' oleh kiai Yanto disini bahwa waktu azan isya' ditetapkan oleh kiai Yanto secara konsisten sepanjang tahun yakni pada pukul 19.05 Wib. Beliau menjelaskan bahwa:

"Sebagaimana telah saya jelaskan tadi, matahari itu terbit dan terbenamnya tidak ajeg, akibatnya waktu isya pun juga berubah ubah, bisa jam 7 malam kurang, bisa jam 7 lebih. Seperti yang sebelumnya, agar mudah di ingat warga, meskipun jam 7 mereka sudah di rumah, kalau bisa isya itu ajeg, dan tidak terlalu malam atan terlalu sore. Tidak terlalu malam, karena warga ingin segera bisa istirahat setelah salat jamaah, sehingga saya tetapkan azan isya' jam 7.05 malam insya allah itu waktu pas tengah-tengah tidak terlalu malam, dan tidak terlalu sore". ${ }^{36}$

\footnotetext{
34 ibid

35 Azhari, Susiknan, Perjumpaan Khazanah Islam dan Sains Modern, Yogyakarta:Suara Muhammadiyah. 2007) hlm 66-67

36 Wawancara dengan kiai yanto pada tanggal 12 September 2019
} 
Berdasarkan uraian-uraian di atas mulai dari analisis peran kiai desa mengintegrasikan waktu salat dan kearifan lokal dalam penetapan jadwal azan salat shubuh hingga isya, dapat ditarik sebuah kesimpulan sederhana terkait latar belakang dalam penetapan jadwal waktu salat di Musholla alFaruq yang ada di Dusun Datar Desa Putukrejo Kecamatan Loceret Kabupaten Nganjuk Jawa Timur, Kiai Yanto dalam menetapkan jadwal azan yang ada mempertimbangkan dua aspek yaitu budaya kerja warga sekitar, yang selanjutnya hal ini oleh penulis di sebut sebagai kearifan lokal. Aspek kedua yaitu terkait dengan ajaran agama tentang pentingnya jamaah salat bagi umat Islam. Pentingnya jamaah salat ini yang merupakan karakter yang diharapkan oleh Kiai Yanto atas ikhtiar yang dilakukannnya dalam penetapan jadwal azan di musholla yang di pimpinnya.

\section{KESIMPULAN}

Berdasarkan urain yang telah dilakukan dapat diperoleh kesimpulan bahwa kiai desa di Jawa Timur terkait dengan penetapan jadwal azan yang ada di mushollanya dengan cara mengintegrasikan waktu salat dengan kearifan lokal yang ada dalam lingkungan jamaah yang di pimpinnya. Terkait dengan tujuan yang diharapkan oleh kiai yanto yaitu jamaah yang dipimpinnya yaitu selalu bisa ikut jamaah salat lima waktu.

\section{DAFTAR PUSTAKA}

Azhari, Susiknan, 2007. Perjumpaan Khazanah Islam dan Sains Modern, Yogyakarta:Suara Muhammadiyah.

Butar Butar, Arwin, 2015. Eai Esai Astronomi Islam, Medan, UMSU Press, Chaq, M. D. "Penerapan Fiqh Di Tengah Perbedaan Madhhab Hukum Islam”. Tafáqquh: Jurnal Penelitian Dan Kajian Keislaman, vol. 7, no. 2, Jan. 2020, pp. 51-66, doi:10.52431/tafaqquh.v7i2.217.

Iin Warrin Bayari. 2014, Nilai-Nilai Kearifan Lokal (Lokal Wisdom) Tradisi Memitu Pada Masyarakat Cirebon(Studi Masyarakat Desa Setupatok. Kecamatan Mundu), Edunomic Jurnal Volume 2 No. 1

Masroratul Fadlilah, 2018. Kepemimpinan Kiai Di Pondok Pesantren Mahasiswa Al-jibad Surabaya (Surabaya: UINSA,

Moleong, Lexy J, 2005. Metodologi Penelitian Kualitatif, Bandung: PT Remaja Rosdakarya,

Riza, M. Fahmi, 2012. Studi Analisis Jadwal Salat Sepanjang Masa H. Abdurrani Mahmud DalamPerspektif Astronomi. Semarang: Tesis Pasca IAIN Walisongo. 
Rizal, Faisol "Agama Dalam Pluralitas Budaya”. Tafáqquh: Jurnal Penelitian Dan Kajian Keislaman, vol. 7, no. 2, Desember 2019, https://doi.org/10.52431/tafaqquh.v7i2.221

Salam, Abd. Ilmu Falak Praktis Waktu Salat, arah kiblat, dan kalender Hijriyah). Surabaya: UINSA,tt\

Suryana, 2010. Metodologi Penelitian, Bogor: Universitas Pendidikan Indonesia.

Sutinah. 2006. Sistem Informasi Penjadwalan Waktu Salat Berbasis Mikrokontroler ATMega16. Bekasi: Informatics For Educators And Professionals P2M STMIK BINA INSANI,

Trisno, Widodo Yudi. 2018. Gaya Kepemimpinan Kiai Yusuf Dalam Pengembangan Pondok Pesantren Assalafi Al-Aafiyy'ah Waylaga Sukabumi Kota Bandar Lampung,Lampung: UIN Raden Intan., Wawancara dengan bapak Sugito Pada Tanggal 12 Agustus 2019 Wawancara Dengan Bapak Romlan Pada Tanggal 13 Agustus 2019 Wawancara dengan kiai yanto pada tanggal 12 September 2019 wawancara dengan ibu Patminah pada tanggal 29 Agustus 2019 Wawancara dengan kiai yanto pada tanggal 12 September 2019 https://www.jadwalsalat.org/adzan/monthly.php? q=c9d4d261da\&type $\equiv 2 \& \mathrm{id}=167 \& \mathrm{~m}=2 \& \mathrm{y}=2019$ 